\title{
Analisis Kinerja Anggaran Pendapatan dan Belanja Daerah pada Pemerintah Provinsi Sulawesi Tenggara Tahun Anggaran 2016-2020
}

\author{
Lia Hanifa ${ }^{1^{*}}$ \\ ${ }^{1}$ Universitas Muhammadiyah Buton, Indonesia \\ *Korespondensi: um.buton@gmail.com
}

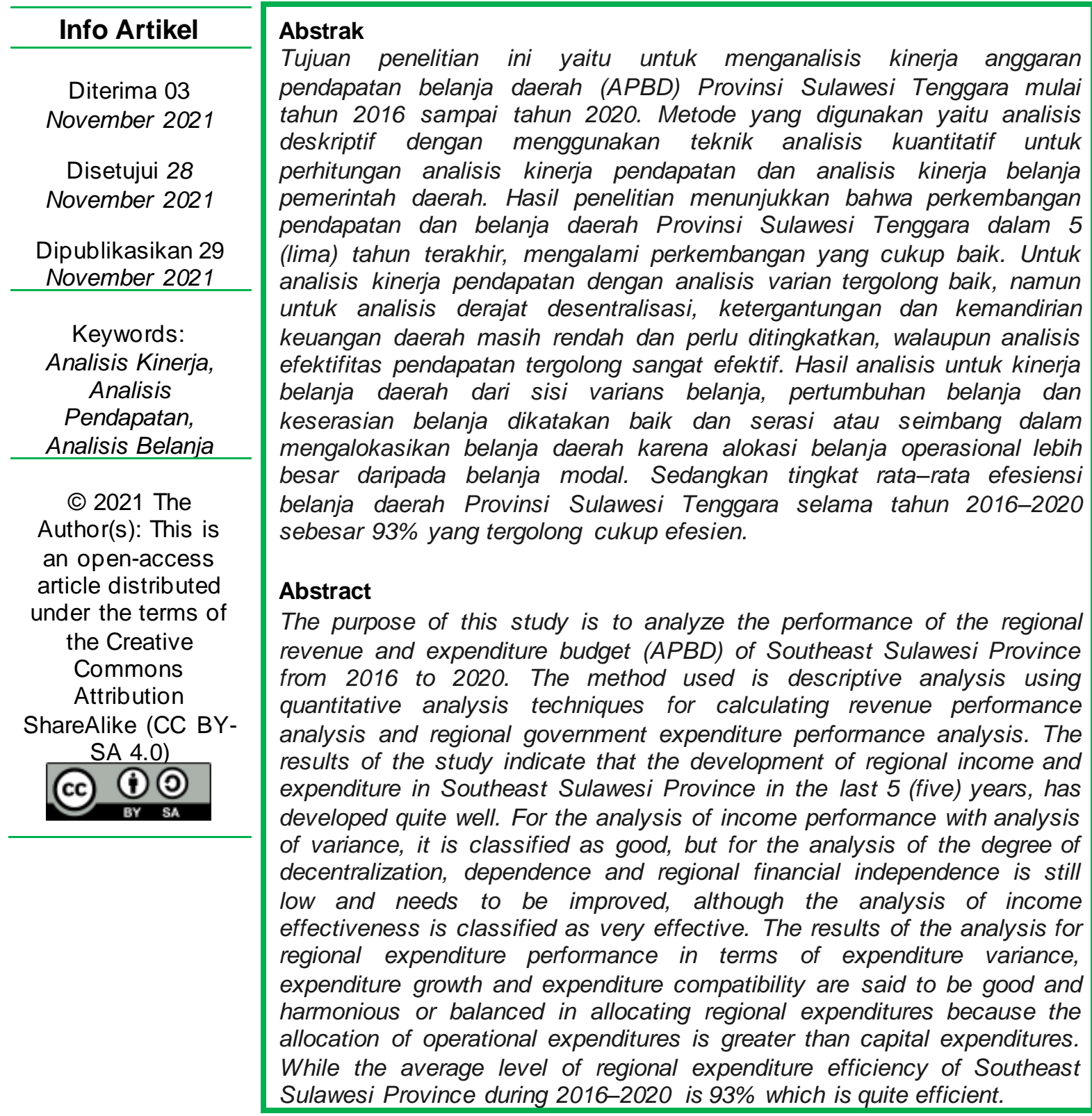




\section{Pendahuluan}

Menurut ketentuan Undang-Undang Nomor 23 Tahun 2014 Tentang Pemerintah Daerah (2014), penyelenggaraan pemerintahan didasarkan pada konsep desentralisasi, dekonsentrasi, dan tugas pembantuan; sebagai hasil dari desentralisasi, pemerintah provinsi dan kota dibentuk dan diatur sebagai daerah otonom. Otonomi daerah mengacu pada kemampuan daerah untuk membuat keputusan daerah yang luas tentang pengelolaan sumber daya sejalan dengan keputusan, prioritas, dan kapasitas daerah (Hadisantoso et al., 2020). Oleh karena itu kesiapan pemerintah daerah menjadi prioritas utama dalam menjalankan otonomi daerah khususnya dalam mengembangkan potensi sumber daya daerah untuk menghasilkan serta mengelola anggaran yang ada untuk kepentingan pembangunan dan pelayanan masyarakat (Halim \& lqbal, 2012).

Salah satu unsur yang dinilai adalah kompetensi pengelolaan dana daerah sesuai Permendagri 59 Tahun 2007. Pengelolaan keuangan daerah sangat berpengaruh terhadap masa depan pembangunan daerah. Pembangunan daerah yang di sertai pengelolaan asset daerah tidak hanya melibatkan sumber daya manusia, akan tetapi juga modal ekonomi yang terkelola dengan baik, sebagaimana yang tertuang dalam anggaran pendapatan dan belanja daerah yang sudah direncanakan. Anggaran pendapatan dan belanja daerah merupakan instrumen kebijakan yang berperan besar dalam menahan kinerja, baik secara internal maupun dalam hal mendorong pertumbuhan ekonomi yang bermanfaat bagi kesejahteraan masyarakat. Menurut Labi (2019) kinerja anggaran pendapatan dan belanja daerah merupakan perbandingan komponen anggaran pendapatan dan belanja daerah (APBD)

Menurut Permendagri nomor 32 tahun 2008, APBD adalah rencana keuangan tahunan yang disahkan oleh Dewan Perwakilan Rakyat Daerah atau DPRD untuk pemerintah daerah di Indonesia. APBD ditetapkan dalam undangundang daerah, dan tahun anggaran APBD adalah satu tahun, dimulai pada tanggal 1 Januari dan berakhir pada tanggal 31 Desember. Analisis kinerja keuangan dalam APBD dilakukan dengan membandingkan hasil dari satu peri ode ke periode sebelumnya secara beru rutan (Pilat \& Morasa, 2017).

Penelitian ini menyajikan ringkasan kinerja fiskal Pemerintah Provinsi Sulawesi Tenggara dari tahun 2016 hingga tahun 2020. Lima tahun terakhir dipilih karena penelitian ini membutuhkan beberapa tahun perbandingan untuk mendapatkan kesimpulan tentang implementasi atau realitas APBD Pemerintah Provinsi Sulawesi Tenggara. Para peneliti sebelumnya telah melakukan kajian ekstensif tentang analisis kinerja dan realisasi APBD secara umum, seperti Labi (2019) yang melakukan penelitian di Kabupaten Pulau Morotai dengan menggunakan analisis data APBD 2013-2015. (Tulangow et al., 2019) melakukan penelitian serupa di Kabupaten Minahasa dengan menganalisis data APBD 2013 2014. Setelah itu, (Honga \& Illat, 2014) melakukan penelaahan terhadap pelaksanaan APBD di Kota Bitung selama tahun anggaran 2013.

Berdasarkan hal tersebut di atas, maka permasalahan penelitian adalah "Bagaimana kinerja Anggaran Pendapatan dan Belanja Daerah (APBD) pada Pemerintah Daerah Provinsi Sulawesi Tenggara Tahun Anggaran 2016-2020?" Sedangkan nilai dari penelitian ini adalah dapat membantu Pemerintah Provinsi Sulawesi Tenggara meningkatkan kinerja keuangan daerah melalui pelaksanaan 
APBD, serta memberikan kontribusi bagi kemajuan ilmu akuntansi, khususnya akuntansi sektor publik.

\section{Metode Penelitian}

\subsection{Jenis dan Sumber Data}

Analisis menggunakan data kuantitatif dari APBD dan laporan realisasi anggaran Provinsi Sulawesi Tenggara tahun anggaran 2016-2020. Studi ini mengandalkan data sekunder, yang dikumpulkan dari sumber lain atau melalui makalah (Kualitatif dan R\&D. Sugiyono, 2017).

\subsection{Teknik Analisis Data}

Teknik analisis data yang digunakan dalam penelitian ini adalah teknik analisis kuantitatif, yaitu dengan menghitung data keuangan yang terdapat dalam APBD dan LRA Provinsi Sulawesi Tenggara tahun anggaran 2016 - 2020 yang diperoleh, untuk menganalisis permasalahan yang sesuai dengan tujuan penelitian. Rumus untuk menghitung kinerja APBD adalah sebagai berikut (Mahmudi, 2010):

a. Analisis Varians Pendapatan Daerah

Rumus = Realisasi Pendapatan Daerah - Anggaran Pendapatan Daerah

Tabel 1. Kriteria Varians Pendapatan Daerah

\begin{tabular}{cc}
\hline Kriteria & Ukuran \\
\hline Baik & Realisasi Pendapatan $>$ Anggaran \\
& Pedapatan \\
\hline Kurang Baik & Realisasi Pendapatan $<$ Anggaran \\
& Pedapatan \\
\hline
\end{tabular}

Sumber: (Mahmudi, 2010).

b. Analisis Derajat Desentralisasi

Rumus $=$ Pendapatan Asli Daerah $\times 100 \%$

Total Pendapatan Daerah

Tabel 2. Kriteria Penilaian Tingkat Derajat Desentralisasi

\begin{tabular}{cc}
\hline Kriteria & Ukuran $(\%)$ \\
\hline Sangat Kurang & $<10$ \\
\hline Kurang & $10,1-20$ \\
\hline Sedang & $20,1-30$ \\
\hline Cukup & $30,1-40$ \\
\hline Baik & $40,1-50$ \\
\hline Sangat Baik & $>50$ \\
\hline
\end{tabular}

Sumber: Tim Litbang Depdagri - Fisipol UGM (Bisma et al., 2010).

c. Analisis Ketergantungan Keuangan Daerah

Rumus $=\underline{\text { Pendapatan Transfer }} \times 100 \%$

Total Pendapatan Daerah 
Tabel 3. Kriteria Penilaian Tingkat Ketergantungan Keuangan Daerah

\begin{tabular}{cc}
\hline Kriteria & Ukuran $(\%)$ \\
\hline Sangat Kurang & $<10$ \\
\hline Kurang & $10,1-20$ \\
\hline Sedang & $20,1-30$ \\
\hline Cukup & $30,1-40$ \\
\hline Tinggi & $40,1-50$ \\
\hline Sangat Tinggi & $>50$ \\
\hline
\end{tabular}

Sumber: Tim Litbang Depdagri - Fisipol UGM (Bisma et al. (2010).

d. Analisis Kemandirian Keuangan Daerah

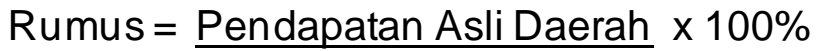

Transfer dan Pinjaman

Tabel 4. Kriteria Penilaian Tingkat Kemandirian Keuangan Daerah

\begin{tabular}{cc}
\hline Kriteria & Ukuran $(\%)$ \\
\hline Rendah Sekali & $<25$ \\
\hline Rendah & $25,1-50$ \\
\hline Sedang & $50,1-75$ \\
\hline Tinggi & $75,1-100$ \\
\hline
\end{tabular}

Sumber: (Halim, 2014).

e. Analisis Efektifitas PAD

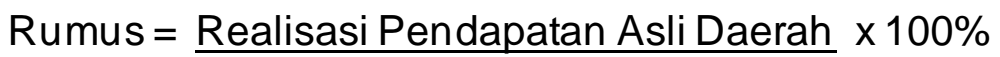

Anggaran Pendapatan Asli Daerah

Tabel 5. Kriteria Penilaian Tingkat Efektifitas PAD

\begin{tabular}{cc}
\hline Kriteria & Ukuran $(\%)$ \\
\hline Sangat Efektif & $>100$ \\
\hline Efektif & 100 \\
\hline Cukup Efektif & $90-99$ \\
\hline Kurang Efektif & $75-89$ \\
\hline Tidak Efektif & $<75$ \\
\hline
\end{tabular}

Sumber: (Mahmudi, 2010).

f. Analisis Varians Belanja

Rumus = Realisasi Belanja Daerah - Anggaran Belanja Daerah

Tabel 6. Kriteria Varians Belanja

\begin{tabular}{cc}
\hline Kriteria & Ukuran \\
\hline Baik & Realisasi Belanja < Anggaran Belanja \\
\hline Kurang Baik & Realisasi Belanja $>$ Anggaran Belanja \\
\hline
\end{tabular}

Sumber: (Mahmudi, 2010).

g. Analisis Pertumbuhan Belanja

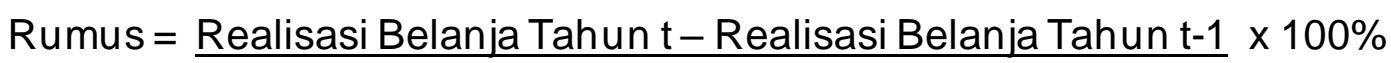
Realisasi Belanja Tahun t-1 
Tabel 7. Kriteria Penilaian Pertumbuhan Belanja

\begin{tabular}{cc}
\hline Kriteria & Ukuran \\
\hline Naik & Positif \\
\hline Turun & Negatif \\
\hline
\end{tabular}

Sumber: (Mahmudi, 2010).

h. Analisis Keserasian Belanja

1) Analisis Belanja Operasi terhadap Total Belanja Daerah

Rumus $=\underline{\text { Realisasi Belanja Operasi } \times 100 \%}$

Total Belanja Daerah

2) Analisis Belanja Modal terhadap Total Belanja Daerah

Rumus $=\underline{\text { Realisasi Belanja Modal } \times 100 \%}$

Total Belanja Daerah

Tabel 8. Kriteria Penilaian Keserasian Belanja

\begin{tabular}{cc}
\hline Kriteria & Ukuran $(\%)$ \\
\hline Serasi & $60-90$ (Belanja Operasi) \\
\hline Kurang Serasi & $<60$ atau $>90$ (Belanja Operasi) \\
\hline Serasi & $5-20$ (Belanja Modal) \\
\hline Kurang Serasi & $<5$ atau $>20$ (Belanja Modal) \\
\hline
\end{tabular}

Sumber: (Mahmudi, 2010).

i. Analisis Efesiensi Belanja

Rumus $=\underline{\text { Realisasi Belanja } \times 100 \%}$

Anggaran Belanja

Tabel 9. Kriteria Penilaian Pertumbuhan Belanja

\begin{tabular}{cc}
\hline Kriteria & Ukuran $(\%)$ \\
\hline Tidak Efisien & $>100$ \\
\hline Efisien & $<100$
\end{tabular}

Sumber:(Mahmudi, 2010).

\section{Hasil Penelitian dan Pembahasan}

\subsection{Analisis Varians Pendapatan Daerah}

Analisis varians pendapatan daerah merepresentasikan usaha suatu daerah dalam merealisasikan pendapatan daerah yang telah dianggarkan (Budidarma, 2010). Hasil dari perhitungan varians pendapatan daerah adalah sebagai berikut:

Tabel 10. Hasil Analisis Varians Pendapatan Daerah Provinsi Sulawesi Tenggara

\begin{tabular}{ccccc}
\hline Tahun & Realisasi & Anggaran & Selisih & Kriteria \\
\hline 2016 & $2,807,076,756,255$ & $2,641,119,191,028$ & $165,957,565,227$ & Baik \\
\hline 2017 & $3,534,627,021,770$ & $3,545,198,442,343$ & $(10,571,420,573)$ & $\begin{array}{c}\text { Kurang } \\
\text { Baik }\end{array}$ \\
\hline & & & & Baik \\
2018 & $3,785,562,578,471$ & $3,521,771,323,096$ & $263,791,255,375$ & \\
\hline
\end{tabular}




\begin{tabular}{ccccc}
\hline 2019 & $4,166,543,383,146$ & $4,029,396,384,379$ & $137,146,998,767$ & Baik \\
\hline 2020 & $4,012,335,036,317$ & $4,432,855,469,479$ & $(420,520,433,162)$ & $\begin{array}{c}\text { Kurang } \\
\text { Baik }\end{array}$ \\
\hline
\end{tabular}

Sumber: Data diolah, 2021.

Berdasarkan tabel 10, kajian varians pendapatan daerah di Provinsi Sulawesi Tenggara secara umum dinilai memuaskan. Hal ini ditunjukkan dengan pencapaian pendapatan daerah yang melebihi target atau APBD Provinsi Sulawesi Tenggara tahun 2016, 2018, dan 2019. Temuan tersebut menandakan bahwa kinerja pendapatan Provinsi Sulawesi Tenggara secara keseluruhan mampu memenuhi anggaran pendapatannya. Meskipun pada tahun 2017 dan 2020, pemeriksaan variasi pendapatan Provinsi Sulawesi Tenggara dirasa kurang memuaskan karena realisasi pendapatan lebih kecil dari jumlah yang dianggarkan. $\mathrm{Hal}$ ini disebabkan oleh administrasi PAD yang tidak efisien, yang mengakibatkan rendahnya kontribusi PAD terhadap pendapatan daerah, terutama dalam hal pencapaian penerimaan pajak daerah pada tahun 2020 dan tidak terealisasinya dana perimbangan pada tahun 2017.

\subsection{Analisis Derajat Desentralisasi}

Rasio ini menunjukkan pelimpahan tanggung jawab dari pemerintah pusat kepada pemerintah daerah untuk menggali dan mengelola pendapatan. Hasil dari perhitungan derajat desentralisasi adalah:

Tabel 11. Hasil Tingkat Derajat Desentralisasi Provinsi Sulawesi Tenggara

\begin{tabular}{rrrrl}
\hline Tahun & Pendapatan Asli Daerah & Pendapatan Daerah & $\%$ & Kriteria \\
\hline 2016 & $753,657,954,464$ & $2,807,076,756,255$ & $27 \%$ & Sedang \\
\hline 2017 & $806,304,244,892$ & $3,534,627,021,770$ & $23 \%$ & Sedang \\
\hline 2018 & $903,949,000,785$ & $3,785,562,578,471$ & $24 \%$ & Sedang \\
\hline 2019 & $1,128,441,587,992$ & $4,166,543,383,146$ & $27 \%$ & Sedang \\
\hline 2020 & $1,017,138,016,007$ & $4,012,335,036,317$ & $25 \%$ & Sedang \\
\hline
\end{tabular}

Sumber: Data diolah, 2021.

Berdasarkan derajat desentralisasi yang dihitung pada Tabel 11, Provinsi Sulawesi Tenggara termasuk dalam kategori sedang. Hal ini menunjukkan bahwa meskipun kontribusi PAD terhadap pendapatan daerah masih minim dan terbatasnya keterlibatan PAD atau kemampuan keuangan daerah dalam membiayai operasional pemerintah sendiri, daerah tetap sangat bergantung pada dana perimbangan anggaran negara (APBN). Rendahnya kontribusi PAD disebabkan oleh belum efektifnya pemungutan pajak daerah dan ketidakmampuan daerah mengelola pendapatan daerahnya sendiri dalam rangka pelaksanaan desentralisasi.

\subsection{Analisis Ketergantungan Keuangan Daerah}

Rasio ini menunjukan tingkat ketergantungan pemerintah daerah terhadap pemerintah pusat dalam pelaksanaan otonomi daerah. Berikut ini tabel perhitungan rasio ketergantungan: 
Tabel 12. Hasil Tingkat Ketergantungan Keuangan Daerah Provinsi Sulawesi Tenggara

\begin{tabular}{ccccc}
\hline Tahun & Pendapatan Transfer & Pendapatan Daerah & $\%$ & Kriteria \\
\hline 2016 & $2,053,418,801,791$ & $2,807,076,756,255$ & $73 \%$ & Sangat Tinggi \\
\hline 2017 & $2,728,322,776,878$ & $3,534,627,021,770$ & $77 \%$ & Sangat Tinggi \\
\hline 2018 & $2,881,613,577,686$ & $3,785,562,578,471$ & $76 \%$ & Sangat Tinggi \\
\hline 2019 & $3,038,101,795,154$ & $4,166,543,383,146$ & $73 \%$ & Sangat Tinggi \\
\hline 2020 & $2,995,197,020,310$ & $4,012,335,036,317$ & $75 \%$ & Sangat Tinggi \\
\hline
\end{tabular}

Sumber: Data diolah, 2021.

Berdasarkan Tabel 12, tingkat ketergantungan Provinsi Sulawesi Tenggara berfluktuasi rata-rata $75 \%$, menunjukkan bahwa tingkat ketergantungan dianggap cukup tinggi. Hal ini disebabkan besarnya uang transfer yang diterima APBN, khususnya DAU (Dana Alokasi Umum) dan DAK (Dana Alokasi Khusus). Temu an ini mengungkapkan bahwa Provinsi Sulawesi Tenggara sangat bergantung pada Pemerintah Pusat dalam pelaksanaan otonomi daerah. Kuatnya ketergantungan Provinsi Sulawesi Tenggara terhadap pemerintah pusat akan berdampak pada rendahnya kemandirian daerah provinsi dalam hal pelayanan masyarakat dan pembangunan daerah.

\subsection{Analisis Kemandirian Keuangan Daerah}

Rasio ini digunakan untuk melihat tingkat perbandingan antara PAD dengan Pendapatan Transfer yang menunjukkan tingkat kemampuan daerah dalam membiayai sendiri kegiatan pemerintahan. Berikut ini merupakan tabel perhitungan rasio kemandirian daerah:

Tabel 13. Hasil Tingkat Kemandirian Keuangan Daerah Provinsi Sulawesi Tenggara

\begin{tabular}{ccccc}
\hline Tahun & $\begin{array}{c}\text { Pendapatan Asli } \\
\text { Daerah }\end{array}$ & $\begin{array}{c}\text { Pendapatan Transfer } \\
\text { dan Pinjaman }\end{array}$ & $\%$ & Kriteria \\
\hline 2016 & $753,657,954,464$ & $2,504,014,139,940$ & $30 \%$ & Rendah \\
\hline 2017 & $806,304,244,892$ & $3,226,990,347,898$ & $25 \%$ & Rendah \\
\hline 2018 & $903,949,000,785$ & $3,234,269,327,767$ & $28 \%$ & Rendah \\
\hline 2019 & $1,128,441,587,992$ & $3,544,218,236,294$ & $32 \%$ & Rendah \\
\hline 2020 & $1,017,138,016,007$ & $3,558,690,644,400$ & $29 \%$ & Rendah \\
\hline
\end{tabular}

Sumber: Data diolah, 2021.

Tabel 13 menunjukkan bahwa Provinsi Sulawesi Tenggara memiliki tingkat kemandirian yang rendah dengan pola hubungan konsultatif, yang menyiratkan bahwa intervensi pemerintah pusat sudah mulai berkurang karena daerah dianggap sedikit lebih mampu melaksanakan kebijakan daerah. otonomi. Hal ini menunjukkan bahwa Provinsi Sulawesi Tenggara semakin mampu melaksan akan 
otonomi daerah, dengan peran pemerintah berangsur-angsur berkurang berpihak pada pemerintah daerah. Rendahnya rasio kemandirian disebabkan PAD Provinsi Sulawesi Tenggara masih rendah dibandingkan dengan pendapatan transfer. Minimnya kemandirian Provinsi Sulawesi Tenggara akan berdampak pada tingkat pelayanan yang diberikan kepada masyarakat. Sebab, PAD Provinsi Sulawesi Tenggara tidak bisa diandalkan untuk melayani masyarakat dan terus mengandalkan pendapatan transfer.

\subsection{Analisis Efektifitas PAD}

Rasio Efektifitas PAD menggambarkan kemampuan pemerintah daerah dalam memobilisasi penerimaan PAD yang ditetapkan berdasarkan potensi riil daerah. Berikut hasil perhitungan tingkat Efektifitas PAD:

Tabel 14. Hasil Tingkat Efektifitas Pendapatan Asli Daerah Provinsi Sulawesi Tenggara

\begin{tabular}{|c|r|r|r|l|}
\hline Tahun & Realisasi PAD & Anggaran PAD & $\%$ & Kriteria \\
\hline 2016 & $753,657,954,464$ & $558,392,945,028$ & $135 \%$ & Sangat Efektif \\
\hline 2017 & $806,304,244,892$ & $743,891,514,197$ & $108 \%$ & Sangat Efektif \\
\hline 2018 & $903,949,000,785$ & $620,402,707,096$ & $146 \%$ & Sangat Efektif \\
\hline 2019 & $1,128,441,587,992$ & $905,235,112,379$ & $125 \%$ & Sangat Efektif \\
\hline 2020 & $1,017,138,016,007$ & $1,224,218,532,479$ & $83 \%$ & Efektif \\
\hline
\end{tabular}

Sumber: Data diolah, 2021.

Berdasarkan Tabel 14, rasio efektivitas PAD seringkali tergolong sangat berhasil karena rata-rata $119 \%$ atau lebih. Provinsi Sulawesi Tenggara memiliki skor efikasi sangat efektif lebih besar dari 100\% dari tahun 2016 hingga 2019, menunjukkan bahwa pemerintah daerah sangat efektif dalam menyelidiki dan mengendalikan PAD. Temuan ini sejalan dengan penelitian sebelumnya oleh Hadisantoso, dkk (2020) yang menemukan bahwa efisiensi penggunaan anggaran oleh pemerintah provinsi Sulawesi Tenggara sangat efektif dengan penggunaan biaya yang relative sedikit dengan ou tput realisasi anggaran yang optimal. Namun, pada tahun 2020, efisiensi PAD akan kurang dari 100\%, sebesar $83 \%$, karena penerimaan pajak daerah yang tidak mencukupi dan pengelolaan yang tidak efisien dari potensi daerah yang sebenarnya untuk meningkatkan PAD.

\subsection{Analisis Varians Belanja}

Analisis varians belanja merupakan selisih antara anggaran belanja dan realisasi belanja. Berikut ini tabel perhitungan analisis varians belanja daerah Provinsi Sulawesi Tenggara:

Tabel 15. Hasil Varians Belanja Daerah Provinsi Sulawesi Tenggara

\begin{tabular}{ccccc}
\hline Tahun & Realisasi & Anggaran & Selisih & Kriteria \\
\hline 2016 & $2,663,870,374,406$ & & $(104,892,127,554)$ & Baik \\
\hline
\end{tabular}




\begin{tabular}{ccccc}
\hline \multicolumn{5}{c}{$2,768,762,501,959$} \\
\hline 2017 & $3,554,111,159,552$ & $3,597,160,276,734$ & $(43,049,117,182)$ & Baik \\
\hline 2018 & $3,586,474,436,543$ & $3,560,113,603,424$ & $26,360,833,119$ & $\begin{array}{c}\text { Kurang } \\
\text { Baik }\end{array}$ \\
\hline 2019 & $4,128,549,681,525$ & $4,245,329,144,386$ & $(116,779,462,861)$ & Baik \\
\hline 2020 & $4,198,430,219,113$ & $5,757,129,238,435$ & $(1,558,699,019,322)$ & Baik \\
\hline
\end{tabular}

Sumber: Data diolah, 2021.

Berdasarkan Tabel 15, analisis varians belanja daerah secara umum berdasarkan kriteria penilaian Mahmudi (2010) menunjukkan bahwa kinerja belanja Provinsi Sulawesi Tenggara dapat tergolong baik, artinya provinsi te rsebut mampu memanfaatkan dan mengendalikan anggaran belanja. agar tetap dalam anggaran yang ditetapkan. Pada tahun 2018, variasi belan ja melebihi anggaran, karena adanya peningkatan belanja barang dan jasa, serta penanaman modal, yang dibarengi dengan peningkatan belanja bagi hasil dan dukungan keuangan kepada pemerintah kabupaten/kota/desa.

\subsection{Analisis Pertumbuhan Belanja}

Hasil perhitungan atau analisis pertumbuhan belanja Provinsi Sulawesi Tenggara untuk tahun anggran 2016 sampai 2020 dapat ditunjukan pada tabel berikut:

Tabel 16. Hasil Pertumbuhan Belanja Provinsi Sulawesi Tenggara

\begin{tabular}{llrrc}
\hline Tahun & Realisasi t & Realisasi t-1 & $\%$ & Kriteria \\
\hline 2016 & $2,663,870,374,406$ & & $0 \%$ & - \\
\hline 2017 & $3,554,111,159,552$ & $2,663,870,374,406$ & $33 \%$ & Positif \\
\hline 2018 & $3,586,474,436,543$ & $3,554,111,159,552$ & $1 \%$ & Positif \\
\hline 2019 & $4,128,549,681,525$ & $3,586,474,436,543$ & $15 \%$ & Positif \\
\hline 2020 & $4,198,430,219,113$ & $4,128,549,681,525$ & $2 \%$ & Positif \\
\hline
\end{tabular}

Sumber: Data diolah, 2021.

Berdasarkan temuan perhitungan rasio pertumbuhan pada Tabel 16, pertumbuhan belanja Provinsi Sulawesi Tenggara dari tahun 2016 hingga tahun 2020 secara umu m cukup baik. Hal ini ditunjukkan dengan rata-rata pertu mbu han yang positif sebesar 13\%. Tingkat kenaikan terbesar terjadi pada tahun 2017 sebesar 33\%, sedangkan tingkat kenaikan terendah terjadi pada tahun 2018 sebesar $1 \%$. Dengan demikian, yang diukur dari pertumbuhan belanja, kinerja anggaran dan realisasi belanja daerah di Provinsi Sulawesi Tenggara periode 2016-2020 tumbuh atau positif.

\subsection{Analisis Keserasian Belanja}

Analisis keserasian belanja daerah bermanfaat untuk mengetahui keseimbangan alokasi dana belanja daerah. Berikut ini tabel perhitungan tingkat keserasian belanja daerah Kabupaten Morowali: 
Tabel 17. Hasil Analisis Keserasian Belanja atas Belanja Operasi terhadap Belanja Daerah Provinsi Sulawesi Tenggara

\begin{tabular}{lllll}
\hline Tahun & Belanja Operasi & Total Belanja & $\%$ & Kriteria \\
\hline 2016 & $1,574,546,685,240$ & $2,663,870,374,406$ & $59 \%$ & $\begin{array}{r}\text { Kurang } \\
\text { Serasi }\end{array}$ \\
\hline 2017 & $2,316,456,949,024$ & $3,554,111,159,552$ & $65 \%$ & Serasi \\
\hline 2018 & $2,456,548,906,760$ & $3,586,474,436,543$ & $68 \%$ & Serasi \\
\hline 2019 & $2,548,945,885,374$ & $4,128,549,681,525$ & $62 \%$ & Serasi \\
\hline 2020 & $2,692,850,494,992$ & $4,198,430,219,113$ & $64 \%$ & Serasi \\
\hline
\end{tabular}

Sumber: Data diolah, 2021.

Pengeluaran operasional adalah pengeluaran yang manfaatnya digunakan dalam satu tahun anggaran, membuatnya bersifat sementara dan, dalam situasi tertentu, rutin dan berulang. Biaya pegawai, biaya produk dan jasa, biaya bunga, hibah dan bantuan sosial semuanya termasuk dalam kategori biaya operasional. Berdasarkan tabel 17, antara tahun 2016 sampai dengan tahun 2020, penetapan belanja operasional untuk belanja daerah di Provinsi Sulawesi Tenggara sudah selaras dan seimbang menurut kriteria (Mahmudi, 2010), dengan rata-rata lebih dari $60 \%$ atau $64 \%$.

Tabel 18. Hasil Analisis Keserasian Belanja atas Belanja Modal terhadap Belanja Daerah Provinsi Sulawesi Tenggara

\begin{tabular}{lrcrc}
\hline Tahun & Belanja Modal & Total Belanja & $\%$ & Kriteria \\
\hline 2016 & $751,917,122,616$ & $2,663,870,374,406$ & $28 \%$ & Kurang Serasi \\
\hline 2017 & $903,121,911,901$ & $3,554,111,159,552$ & $25 \%$ & Kurang Serasi \\
\hline 2018 & $795,197,262,263$ & $3,586,474,436,543$ & $22 \%$ & Kurang Serasi \\
\hline 2019 & $1,194,738,481,989$ & $4,128,549,681,525$ & $29 \%$ & Kurang Serasi \\
\hline 2020 & $1,048,329,030,395$ & $4,198,430,219,113$ & $25 \%$ & Kurang Serasi \\
\hline
\end{tabular}

Sumber: Data diolah, 2021.

Berdasarkan tabel 18, pemeriksaan kesesuaian belanja modal dengan belanja daerah di Provinsi Sulawesi Tenggara tidak meyakinkan, karena proporsi rata-rata belanja modal provinsi melebihi $20 \%$, atau $26 \%$, menurut kriteria (Mahmudi, 2010). Pemerintah daerah dengan pendapatan daerah yang rendah seringkali menghabiskan lebih banyak anggarannya untuk proyek-proyek modal daripada pemerintah daerah dengan pendapatan daerah yang tinggi. Ini karena pemerintah daerah berpenghasilan rendah lebih cenderung terlibat dalam belan ja modal aktif sebagai bagian dari investasi modal jangka panjang, sedangkan pemerintah daerah berpenghasilan tinggi sering kali memiliki aset modal yang cukup. Dengan demikian, PAD Provinsi Sulawesi Tenggara masih rendah.

\subsection{Analisis Efesiensi Belanja}

Rasio efisiensi belanja daerah ini digunakan untuk mengukur tingkat penghematan anggaran yang dilakukan pemerintah daerah. Berikut ini tabel analisis efisiensi belanja daerah:

Tabel 19. Hasil Analisis Efisiensi Belanja Daerah Provinsi Sulawesi Tenggara

\begin{tabular}{ccccc}
\hline Tahun & Realisasi & Anggaran & $\%$ & Kriteria \\
\hline 2016 & $2,663,870,374,406$ & $2,768,762,501,959$ & $96 \%$ & Efisien \\
\hline
\end{tabular}




\begin{tabular}{lllcc}
\hline 2017 & $3,554,111,159,552$ & $3,597,160,276,734$ & $99 \%$ & Efisien \\
\hline 2018 & $3,586,474,436,543$ & $3,560,113,603,424$ & $101 \%$ & Tidak Efisien \\
\hline 2019 & $4,128,549,681,525$ & $4,245,329,144,386$ & $97 \%$ & Efisien \\
\hline 2020 & $4,198,430,219,113$ & $5,757,129,238,435$ & $73 \%$ & Efisien \\
\hline
\end{tabular}

Sumber: Data diolah, 2021.

Seperti terlihat pada Tabel 19, efektivitas belanja daerah di Provinsi Sulawesi Tenggara bervariasi dari tahun ke tahun. Menurut (Mahmudi, 2010), tingkat efisiensi belanja di Provinsi Sulawesi Tenggara baru mencapai kategori tidak efisien pada tahun 2018. Namun, pada tahun-tahun lain rasio efisiensinya ku rang dari $100 \%$, dengan rata-rata $93 \%$. Hal ini menunjukkan bahwa Provinsi Sulawesi Tenggara telah efektif mengelola belanja daerah atau tidak terjadi pemborosan dalam penggunaan anggaran.

\section{Kesimpulan}

Secara umum rasio pertumbuhan belanja telah menunjukan pertumbuhan yang baik dan positif. Hal ini dapat dilihat dari 10 analisis kinerja pendapatan daerah Provinsi Sulawesi Tenggara tahun 2016-2020 antara lain analisis terhadap varians pendapatan, derajat desentralisasi, ketergantungan dan kemandirian keuangan daerah, efektifitas PAD, varians, pertumbuhan, dan keserasian belanja, efisiensi belanja serta analisis keserasian belanja untuk analisis belanja modal terhadap belanja daerah. Analisis kinerja pendapatan daerah dilihat dari analisis varians pendapatan, secara umum tergolong baik. dimana realisasi pendapatan daerah melebihi anggaran yang telah ditetapkan dalam APBD. Sedangkan apabila dilihat dari analisis derajat desentralisasi, secara umum tergolong sedang, den gan rasio rata-rata sebesar $25 \%$. Dari hasil analisis ketergantungan keuangan daerah, secara umum tergolong sangat tinggi, dengan rasio rata-rata sebesar $75 \%$ sebaliknya jika dilihat dari analisis kemandirian keuangan daerah, secara umum tergolong rendah, dengan rasio rata-rata sebesar $29 \%$ dengan pola hubungan konsultatif. Dilihat dari analisis efektifitas PAD, analisis kinerja pendapatan daerah Provinsi Sulawesi Tenggara secara umum tergolong sangat efektif dengan rasio rata-rata sebesar $119 \%$.

Dilihat dari analisis varians belanja terhadap kinerja belanja daerah Provinsi Sulawesi Tenggara, secara umum tergolong Baik, dimana realisasi belanja tidak melebihi anggaran yang telah ditetapkan, sementara itu jika analisis kinerja belanja daerah dilihat dari analisis pertumbuhan belanja, secara umum juga tergolong positif dengan rasio rata-rata sebesar $13 \%$. Hasil Analisis keserasian belanja untuk analisis belanja operasi terhadap belanja daerah tergolong serasi, dengan rasio rata-rata sebesar $64 \%$, sebaliknya jika dilihat dari analisis keserasian belanja untuk analisis belanja modal terhadap belanja daerah, secara umum tergolong kurang serasi, dengan rasio rata-rata sebesar $26 \%$, sementara itu, analisis efesiensi belanja tergolong efisien dengan rasio rata-rata sebesar $93 \%$. 


\section{Daftar Pustaka}

Bisma, Gede, I. D., \& Susanto, H. (2010). Evaluasi Kinerja Keuangan Daerah Pemerintah Provinsi Nusa Tenggara Barat Tahun Anggaran 2003-2007. Jurnal Ganec Swara Edisi Khusus, 4(3).

Budidarma. (2010). Anggaran Pendapatan Belanja Daerah. Erlangga Group.

Hadisantoso, E., Awaluddin, I., \& Nuka, M. (2020). Evaluasi Penentuan Tarif Kamar Hotel dengan Menerapkan Metode Activity Based Costing pada Hotel Zenith Kendari. Jurnal Akuntansi Dan Keuangan, 5(1), 106-121. https://doi.org/http://dx.doi.org/10.33772/jak-uho.v5i1.13405

Halim, A. (2014). Manajemen Keuangan Sektor Publik problematika penerimaan dan pengeluaran pemerintah. Salemba Empat.

Halim, A., \& lqbal, M. (2012). Pengelolaan Keuangan Negara. Bulak Sumur.

Honga, A. ., \& Illat, V. (2014). Analisis Realisasi Anggaran Pendapatan dan Belanja Daerah Pemerintah Kota Bitung. Jurnal EMBA, 2(4), 278-288.

Kualitatif dan R\&D. Sugiyono. (2017). Metode Penelitian Kuantitatif Kualitatif dan $R \& D$. Alfabeta.

Labi, A. (2019). Analisis Kinerja Anggaran Pendapatan dan Belanja Daerah Pada Pemerintah Daerah Kabupaten Pulau Morotai Tahun Anggaran 2013-2015. Jurnal Akuntansi Bisnis Dan Ekonomi, 5(1), 1355-1370.

Mahmudi. (2010). Manajemen Keuangan Daerah. Erlangga Group.

Undang-undang Nomor 23 tahun 2014 tentang pemerintah daerah, (2014).

Pilat, J. J., \& Morasa, J. (2017). Analisis Rasio Keuangan Anggaran Pendapatan dan Belanja Daerah (APBD) Kota Manado untuk Menilai Kinerja Keuangan Pemerintah Kota Manado Tahun Anggaran 2011-2015. ACCOUNTABILITY, $6(1), 45-56$.

Tulangow, C., Santoso, P., \& Lukas, A. Y. H. (2019). Effect of feeding frequency of trash fish on growth of mangrove crab (Scylla serrata) Used battery system. Fakultas Kelautan dan Perikanan, Universitas Nusa Cendana. 50-61p). Aquatik, 2(2), 50-61. 